\title{
The economics of international trade in south-eastern Europe ${ }^{1}$
}

\begin{abstract}
This article looks at issues of trade in south-east Europe and seeks to establish a framework for the political economy of Balkans countries which presents an alternative view of the recent economic development of each one, as well as of the region as a whole. The authors introduce a detailed analysis from which to develop an understanding of the level of globalisation of each of the economies in question, providing detailed statistics for the level of trade, and of imports and exports, of each Balkans country and its level of participation in international trade relationships. This consequently allows us to judge its level of globalisation both in absolute as well as comparative terms. The authors conclude that few Balkans countries are yet sufficiently globalised to allow them to have joined the current surge in international trade, especially in the context of an increasing concentration of trade relationships amongst EU members, although all are showing sufficiently positive signs which may allow them to join such a surge and to take advantage of these patterns in future.
\end{abstract}

Keywords: trade, imports and exports, globalisation, Balkans, CMEA trade arrangements, FDI, competitive advantages, international trade surge, trade patterns within EU, EU accession, future prospects.

\section{Introduction}

In the wake of recent news and developments across the entire Balkan peninsula, the evolution of trade in south-east Europe is becoming of primary concern. All these economies have begun to be confronted with many unexpected challenges that, when viewed in a broader context, could lead to a synergy of the compatible economic (and also rather political) interests (Sergi and Qerimi, 2008). Up to now, the technical debate has been about the pros and cons of a further widening of the European Union to grant membership to the countries that have emerged after the collapse of Yugoslavia (Slovenia alone has been a full member country, since 2004).

The main contribution of this article is that of providing a framework to deal with the trade aspects of the political economy of the Balkan countries. This article considers the recent performance of Balkan economies' and their trade achievements, and explains their impact on national economies. The next section summarises the eco-

1 We are extremely grateful to both the Editor and the Associate Editor of this Journal, Bela Galgoczi and Calvin Allen, for having encouraged us to write on this topic and for their valuable comments on an earlier draft of this article. However, the views expressed in this article are our own. The paper was written while the first author was teaching at New York University in June-August 2008. 
nomic issues over the past decades which may have a link to trade issues. We introduce our statistical analysis and provide a country-by-country international trade analysis from three separate angles:

1. each country's imports and exports are compared to its GDP

2. imports, exports and trade as a percentage of GDP are analysed for each country in the region

3. the imports and exports of each country in the Balkans is also compared to world imports and exports to see whether or not a country is globalising.

Thus, three separate analyses, using three sets of data, are used to determine the levels of globalisation of countries in the Balkans. Our statistical approach generates a new kind of debate and advances an alternative view of economic development in south-eastern Europe. The last section presents a few conclusions.

\section{Some general issues regarding the Balkans}

Profound economic distortions characterised the former communist economies. Based on such distortions and on low competitiveness arose a paternalist style of government (Sergi, 2003) which provided full employment and other benefits to employees, grounded by the communist authorities on the soft budget constraint that is, a trade-off between paternalist government on the one side and, on the other, the least amount of long-run efficiency within firms. A starting point for any fertile discussion about the transformation countries is what distortions they applied either to prices or in terms of where they stood in relation to trade dependence on the Council of Mutual Economic Assistance (CMEA) system, ${ }^{2}$ as well as their domestic output structure. The central planning system played a role in setting quantity and prices - in contrast to market principles - and in guiding the flows of goods and services in the direction of trade. The quantity and price policy determined the structure of domestic output, but the overall system moved in terms of distorted prices, determining the lowest levels of international competitiveness and being patently unfit for a post-transition framework.

Consequently, international trade for all newly-formed independent countries dropped substantially immediately after their independence and this had a large impact on national economies. The dissolution of the social trade system was one major factor in recession, while the international trade multiplier, supply bottlenecks and investment decisions, the terms of trade and wars were all also key factors (Marangos, 2001; Sergi, 2003). It is clear that the fall of CMEA would by itself have brought about a share in the decline in total output and we can state that the countries which were highly dependent on CMEA trade arrangements - examples were Bulgaria and the Baltics - were hit by sizeable recessions. A notable exception is found in the Balkans, where trade and microeconomic distortions were, in the early stages of the transformation, among the lowest in the eastern bloc, although this region suffered the most due to its internal social instability (Bitzenis and Marangos, 2007; Sergi, 2001).

2 The Council for Mutual Economic Assistance, inaugurated in January 1949 and known also as Comecon, functioned as an international economic system for the Soviet bloc; the USSR acted as leader and the other founding members were Bulgaria, Czechoslovakia, Hungary, Poland and Romania. CMEA's Council decided to dissolve the organisation in the spring of 1991 and, in effect, it was disbanded by 1 November. 
But what caused the disintegration of the CMEA system? In fact, a synchronisedtype upsurge in trade links with the west followed, to the point that the west nowadays continues to be the main destination for their exports. A re-orientation in the direction of the markets of the European Union and of consumers is explained as a return to normality in foreign trade through strong downwards corrections to intra-CMEA trade, simply because the enterprise system began to correct the inherited microeconomic distortions. Such distortions entailed less demand for domestic goods and imports from other countries that were behaving in a similarly distorted fashion as regards output. Therefore, the novelty at the level of production and the structure of trade concerning the new undistorted framework started to reflect to a greater extent the comparative advantage of each country rather than the supply decisions taken by central planners.

Interestingly enough, the former Yugoslavia contained fewer distortions than did the neighbouring communist economies (Sergi, 2001 and 2003). The major points to be made about the distortions and industrial structure of these countries are as follows:

a. Primary industries, e.g. mining, dominate most of these economies but, in contrast with other former centrally-planned economies, these were not widely linked in trade terms to the CMEA system. Suppressed inflation adds another layer of information, being a common aspect for all these economies.

b. In all Balkan countries, the weight of industry as a percentage of total GDP is a relevant factor, especially in Bulgaria and Romania where it is as high as 59\%, but, in other economies in the region (e.g. Albania and Croatia), it is more in line with that of Hungary. Over-industrialisation was most keenly felt in Bulgaria and Romania, which showed the highest percentages among the former centrallyplanned economies (respectively, 23\% and 22\%). In Albania and Croatia, the over-industrialisation figure was the lowest (3\% and $1 \%$ respectively). The former Yugoslav economy, on balance, did not display a particularly large degree of overindustrialisation. This partially explains why Balkan countries have quite significant trading relationships with the European Union. Dependence on the CMEA system is another feature of the former Yugoslavia, in that there was not an overdependence and that involvement in CMEA was actually kept low in comparison to other economies (Sergi and Qerimi, 2008).

c. The area is a large one, encompassing fifty million inhabitants and located very close to major countries in Europe and in the east. South-east Europe is the gateway between Europe and Asia. The advantage of such a geographic location is that it provides an additional strength to these countries - as long as they are able to hold on to this opportunity by moving in unison. The region might be attractive to investors as a platform for production for all of south-east Europe, the European Union and other export markets. In fact, the latter argument is particularly relevant to this article's thesis. Actually, the Balkans cannot compete easily with foreign producers without FDI and, through that, access to foreign technology - something of which they themselves must be aware. Recently, researchers have found support for the market size of the host country (as measured by per capita GDP), despite other instrumental variables being sensitive to small alterations in the information set (Bitzenis, 2005; Petrakos, 2002; Sergi and Qerimi, 2006). Concerning the Balkans, achievements with respect to being open both to trade and to low 
wages give a boost to positive expectations and to competitive position. This region has a very skilled labour force, which is well-trained and the least expensive within eastern Europe, while the proposal that they work as a single entity may help them to grab part of the growth in world trade in goods that has been particularly impressive during the last decade, both worldwide and especially in central and eastern Europe (Sergi and Qerimi, 2008).

d. Moreover, estimates provide a valuable perspective on trade specialisation and comparative advantage in 1999. According to SITC categories, all the candidate countries are competitive in miscellaneous manufactured goods (e.g. SITC 8: furniture, bedding, clothing and footwear) although they all show a comparative disadvantage or even de-specialisation in other sectors (e.g. SITC 7: machinery and transport equipment) - excluding, on balance, primary goods (except fuels) in which they do appreciably well. However, a closer look at the data shows two things. First, neighbouring countries such as Hungary enjoy a competitive advantage in selected segments within machinery and transport equipment. Hungary is also strongly competitive in power generating machinery, office machines and telecommunications. Second, countries' positions can change (i.e. a comparative disadvantage can become an advantage). For example, Hungary moved from a disadvantage in office machinery in 1995 to a position of advantage in 1999, while a similar switch of competitiveness took place in Estonia, the Czech Republic, Slovakia and Slovenia. The dynamics in the Czech Republic, Slovakia, Slovenia and Hungary, evidenced in the availability of a youthful labour supply, lower wage rates and being the gateway between east and west, mirrors the focus of FDI on primary goods and low-tech manufacturing.

The Balkans may subsequently become a competitive area for capital-intensive manufactured products; that is, FDI would increase productivity systemically and would also widen the scope of production. If macroeconomic stability and government incentives were added, foreign investors may pump more capital into the region. Overall, there are many benefits to be gained in south-east Europe from FDI and they do not pose a threat to individual countries' national sovereignties (Bitzenis and Marangos, 2007; Sergi and Qerimi, 2008).

\section{Country-by-country analysis}

In this section, each country from the Balkans is evaluated from three separate angles. First, each country's imports and exports are compared to its GDP. At least imports may be considered a function of the nation's productivity, which is measured by its GDP. An increase in the nation's output enables its citizens to increase their consumption of everything, including imports. Exports, however, are usually a function of other countries' incomes. An increase in exports increases GDP, other things being equal. If imports increase faster than exports, one might conclude that imports have an income elasticity greater than 1 . There is another way of looking at an excess of imports over exports when income increases. A nation becoming wealthier consumes more of its goods and services rather than exporting them and also consumes more foreign products; both are a result of the wealth effect. The argument, however, is valid only when income increases.

Second, imports, exports and trade as a percentage of GDP are analysed for each country in the region. Countries have different levels of income and productivity, so it 
makes sense to track their imports and exports as percentages of their respective GDPs. Countries with higher levels of globalisation have, ceteris paribus, higher percentages of trade. During the course of analysis, close attention is paid to other factors, such as changes in GDP, the dominance of imports and sudden shifts in GDP, imports and exports.

Third, if a country starts from a very low level of trade, even a modest increase seems substantial when expressed as a percentage. To avoid any pitfalls, the imports and exports of each country in the Balkans are also compared to global imports and exports. If a country is expanding its trade by a substantial amount, but trade in the rest of the world is expanding by a higher percentage, the country is not, relatively speaking, globalising.

Thus, three separate analyses using three sets of data are used to determine the levels of globalisation of countries in the Balkans. The three datasets are:

1. actual imports, exports and GDP

2. imports, exports and trade as percentages of each country's GDP

3. actual imports and actual exports as percentages of corresponding global values.

Data for imports, exports and GDP, which are all in current US dollars, are from the World Bank's World Development Indicators (2008). Data for imports and exports, as percentages of GDP, are also obtained from the same source.

The authors have benefited from analysing import and export data before turning to the trade data. Therefore, references will at times be made to the disaggregated data although, due to space limitations, these are not depicted in any of the graphs. In all eight presented graphs, the following conventions are used and should be taken into account when examining them.

All data are scaled to improve the readability of the graph. Trade data are in current US dollars divided by 100000 000. All trade lines are represented by a dashed line with diamond-shaped tick marks and marked as 'trade' on the right-hand end of the line in the graph. The unit of measurement, depicted on the left-hand Y-axis, is $\$ 100000000$.

The lines for each country's trade as a percentage of GDP are solid grey lines with square tick marks. They are all marked as 'Trade, \% GDP' at the left-hand edge of the line on the graph. The scale, which is a percentage, is depicted on the left-hand Y-axis as numerals with no decimal place.

The lines for the country's trade as a percentage of world trade are in solid black lines with triangular tick marks. The values of the data are multiplied by 1000 to bring them to a scale comparable to other data and are presented on the right-hand Yaxis for clarity. For example, Albania's trade as a percentage of world trade for 1984 is 0.15 , which means it is equal to 0.015 per cent of world trade, i.e. lower than $0.02 \%$. All the values are very low, so it is best to use the graph to trace the changes instead. In Albania's case, trade was $0.015 \%$ in 1984 and climbed to $0.022 \%$ in 2005 , an increase of over 1.5 times in 22 years.

It is very important not to compare the three lines in each graph with each other. They are not only in different units, $\$$ versus percentages, but also in different scales. 


\section{Albania}

\section{Trade}

Albania's GDP began declining in 1990. In 1992, it suffered a 38\% decline but, in the following year, it bounced back to the 1991 level. Every year since then, GDP has been growing very rapidly, sometimes doubling the percentage growth every two years. In 2005, nominal GDP reached over \$8.4bn. Ironically, in 1992 the drop in GDP coincided with imports more than doubling, while exports experienced a slight decline. Thereafter, both imports and GDP continued to grow rapidly, although the latter grew much faster until 1996. Subsequently, the imports line has been almost parallel to the GDP line. In 1996, exports also picked up momentum and both imports and exports have grown substantially since then. From almost identical beginnings, exports grew 5.6 times while imports grew 10.4 times, creating a massive negative balance of trade by 2005, in excess of 53 times the 1984 figure. Imports exceeded exports by about $11 \%$ in 1984 but, by 2005, the former was more than double the latter. An astute student of Albanian history would immediately see the link between the abrogation of the old constitution in 1991 and the response of GDP, imports and exports. The 1992 election, the reforms in the price mechanism and foreign exchange, among other things, would account for most of the remaining outcomes listed here.

Albania's trade never had any real setback, although there have been occasional slowdowns, such as in 1991 and 1997 (see Figure 1). Since then, trade has had a fairly rapid pace, increasing many times. Based on trade, Albania's (relative) globalisation began in 1997.

\section{Globalisation}

Available data for Albania ranges from 1980 to 2005. Exports as a percentage of GDP start at $23.12 \%$, which is just slightly above the $22.71 \%$ for imports. By 1982 , however, imports as a percentage of GDP exceed the export percentage. The greatest imbalance occurs in 1992, when imports are 88.51\% of GDP while exports are only $11.49 \%$ of GDP. By 1995, imports had declined substantially, but not below the 1991 levels, before again increasing sharply. From 1980 to 1987, imports as a percentage of GDP declined faster than exports as a percentage of GDP, but never throughout this period did exports exceed imports. From 1984 to 1998, the value of exports as a percentage of GDP declined gradually. However, the reason for the decline in this percentage is the rapid growth of GDP, not a decline in actual exports. During this period, exports hovered around $\$ 300 \mathrm{~m}$. In 1999, exports began to increase, tripling in value by 2005. Therefore, the increase in Albania's trade, at least until 1998, has been due to an increase in imports, fuelled in part by the rapid increase in GDP.

The jump in trade as a percentage of GDP in 1992 was very unusual. Even in 2005, the corresponding figure was still way below the level of 1992. Excluding 1992, however, trade as a percentage of GDP has shown a relatively smooth upward trend, indicating that, over the 22-year period under study, trade increased faster than GDP. The extremely unusual spike in imports can be attributed to the demand for non-Albanian goods by United Nations (UN) peace-keeping forces. 


\section{Figure 1 - Albania's trade: actual, as \% of GDP and as \% of world trade}

\section{Albania, 1984-2005}

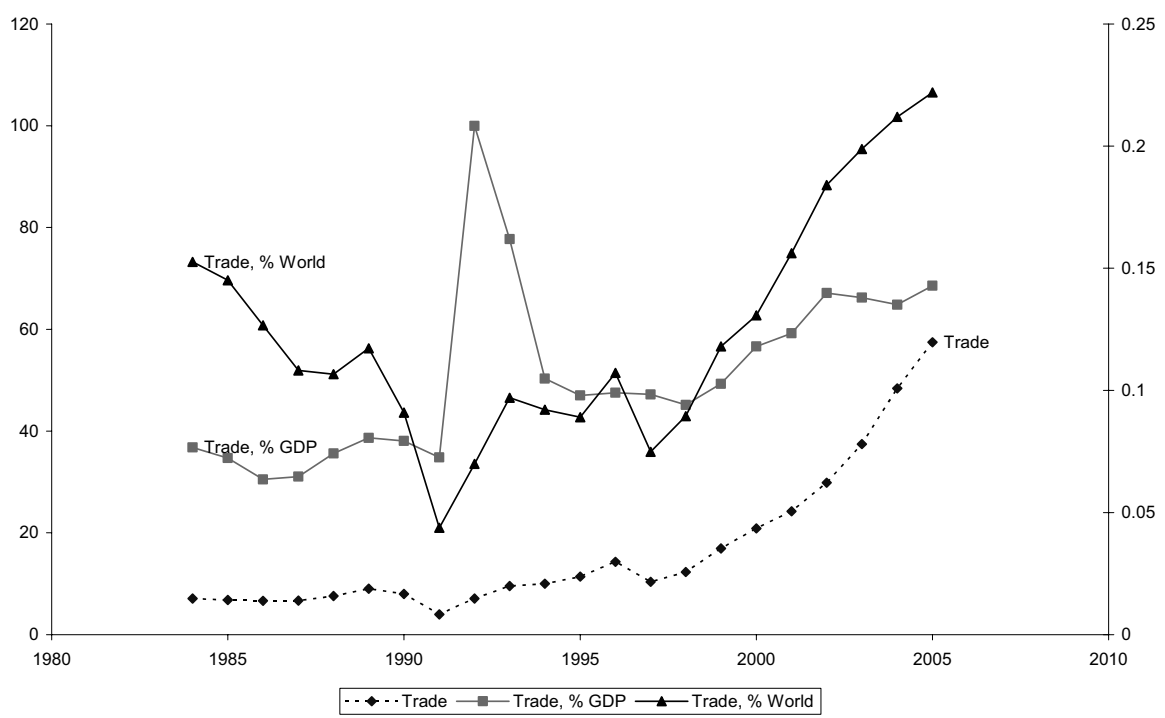

Note: The values for trade (scaled) and trade as a \% of GDP are shown on the left, while that of trade as a \% of world trade (scaled) is shown on the right-hand side.

\section{Globalisation compared to the world}

Imports and exports, which are plotted, may be divided by the corresponding values for the world. The actual numbers are very small, since the countries and their trade are small. If each country had the same share of world trade, the amount would have been close to one half of one per cent, since there are about two hundred countries in the database. Thus, the magnitude is not as important as the changes over time depicted by this line.

Albania's share of world imports was slightly higher in 1984 than its share of exports. Initially, both percentages decline but, in 1991, recovery starts and continues to overcome the initial decline in imports, although not for exports. Eventually, the share of imports almost doubled but exports never caught up with their original high. In spite of some weak performances, Albania is on the verge of globalisation.

The weak points are that imports, exports and trade as a percentage of GDP are rather low (the maximum is about $100 \%$ but mostly it is less than $70 \%$ ). Secondly, the country's share of world trade is small; however, that is mostly due to the country's small size. Thirdly, imports dominate trade and are much higher than exports. On the other hand, the country's share of world trade and its own GDP has been increasing rapidly since 1997. Albania's trade as a percentage of world trade shows a substantial decline from 1984 to 1991. Since then, with the exception of 1997 and, to a lesser extent, 1995, the percentages have been increasing rapidly, showing solid signs of globalisation since 1997. In order to be a truly globalised nation, Albania needs to in- 
crease its exports substantially. Albania's significantly higher imports in relation to its exports are not sustainable in the long run.

\section{Bosnia and Herzegovina}

\section{Trade}

The data for Bosnia and Herzegovina begin in 1994. From the beginning of this period, imports have exceeded exports by a magnitude of 5.6 times (over \$1bn in 2005 as opposed to below $\$ 200 \mathrm{~m}$ in 1994). From 1994 to 2005, imports grew at an impressive rate, increasing by almost 7.4 times; however, the growth in exports is even more impressive, nearing 18.6 times. The monumental increase in exports has reduced the relative discrepancy between imports and exports. Nevertheless, in 2005 the trade deficit exceeded $\$ 4.4 \mathrm{bn}$ compared to $\$ 891 \mathrm{~m}$ in 1994 . It is important to note that the country's GDP never once declined from 1994 to 2005. Uninterrupted growth over eleven years has resulted in an increase in GDP of over 8.5 times, while the growth rate is well over $16.6 \%$ per year over these eleven years, even when GDP is measured in constant dollars (actual numbers not shown). Perhaps it is justified to share the fruits of growth, even if it means having a trade deficit when the country is growing so rapidly. Figure 2 reveals the substantial gain in trade. The trend in trade has been upwards, with absolutely no decline at any point between 1995 and 2005, although the rate of growth was faster between 1994 and 1999 and between 2002 and 2005.

Figure 2 - Bosnia and Herzegovina's trade: actual, as \% of GDP and as \% of world trade

Bosnia and Herzegovina, 1994-2005

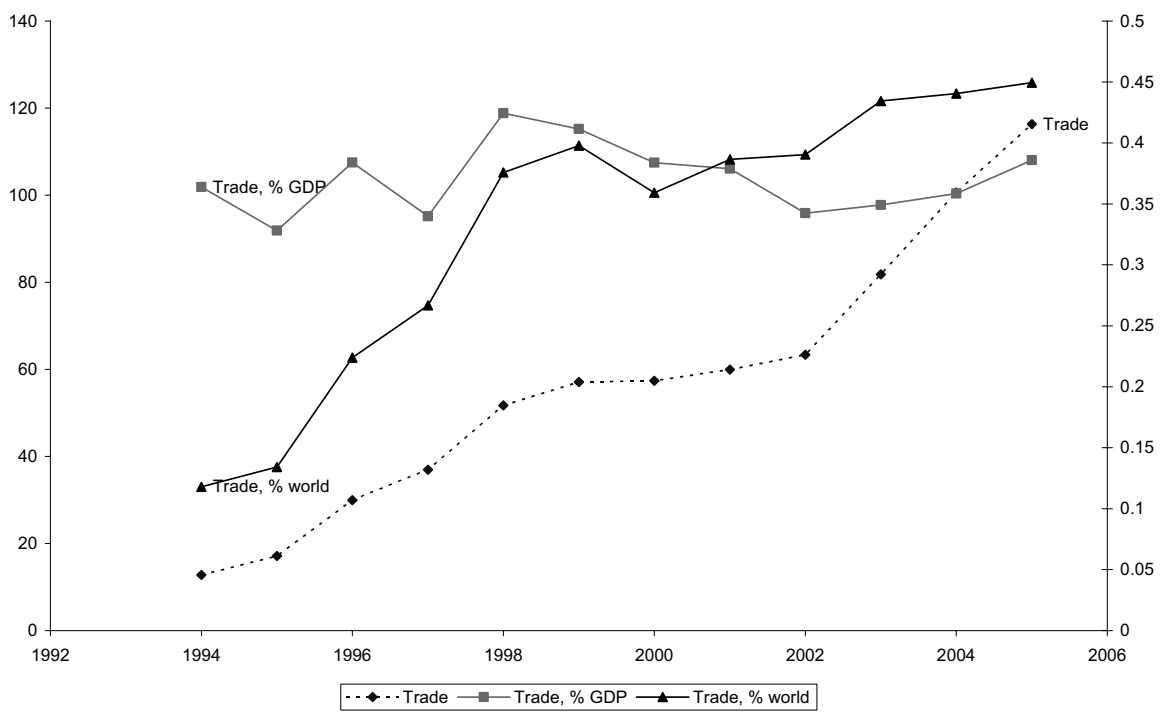

Note: The values for trade (scaled) and trade as a \% of GDP are shown on the left, while that of trade as a \% of world trade (scaled) is shown on the right-hand side. 


\section{Globalisation}

Imports as a percentage of GDP exceed exports as a percentage of GDP by 5.59 times ( $86.40 \%$ compared to $15.44 \%$ ). The ratio has dropped gradually, as far as 2.23 times in 2005 (74.58\% compared to $33.47 \%)$. After imports declined from $86 \%$ of GDP in 1994 to $69 \%$ in 1997, it jumped to $93 \%$ of GDP in 1998, after which time it declined gradually until 2004 before reporting a modest gain in 2005. The sudden and substantial increase in imports in 1998 (almost \$1.4m) and the pursuant high value of 1999 are unusual when the overall trend is considered. A possible drawback is that the continued growth in exports and imports in Bosnia and Herzegovina is largely due to the presence of the international peace-keeping forces: the figures would surely look radically different in the absence of the mission supported by the UN.

The exports path is much smoother, depicting a gradual and persistent increase over the entire period. This increase, combined with a decline in imports which was more erratic in the early years, has helped to reduce the gap in exports and imports as percentages of GDP. This does not mean that the trade imbalance has reduced. In fact, the negative balance of trade worsened, from \$891m in 1994 to $\$ 4.4 \mathrm{bn}$ in 2005. This gap in the percentages declined as a result of the increase in GDP, which increased by well over 750 percentage points over this period.

Bosnia and Herzegovina's imports, and more so its exports, have increased substantially in the period. The line representing trade as a percentage of GDP seems flat overall, but does have several substantial dips. This reveals one of the weaknesses of using 'trade as a percentage of GDP' as a measure of globalisation: the reason for the flat line is that, while trade was climbing, GDP was doing the same while, at times, it grew even more rapidly than trade. Thus, it seems that trade might have declined, which is far from the reality. The joint increase in GDP and exports, and the pursuant increase in imports, is a healthy sign of a growing economy which is opening up and integrating increasingly into the world community.

\section{Globalisation compared to the world}

As expected, Bosnia and Herzegovina's imports had a much higher share of world trade than its exports. Imports have not grown as fast as exports; nevertheless, exports still have a much smaller share of the world market than imports due to a lower starting position. In fact, exports as a share of world exports grew by more than 7.8 times while imports as a share of world imports grew 3.1 times. Figure 2 above reveals that Bosnia and Herzegovina's share of world trade has been climbing almost non-stop. The greatest expansion of trade as a percentage of world trade occurred between 1994 and 1999. It was explained earlier that this increase in the share of world trade was due to an increase in imports to meet the extra demands of UN forces. However, this does not take anything away from the export record, which has been growing in a steady upwards direction. The share of both exports and imports has increased substantially and, in light of total trade exceeding 100\% of GDP, Bosnia and Herzegovina may be considered globalised, at least mildly. 
Bulgaria

\section{Trade}

Compared to other countries in the Balkans, Bulgaria's GDP starts at a fairly high level (over \$20bn). After some ups and downs, it dropped substantially in 1994 to $\$ 9.7 \mathrm{bn}$ since which time it gradually improved up to 2004 , at which point it finally surpassed the 1980 level. However, the country is still below its historic high GDP, which was in 1987. In 1980, Bulgaria's exports exceeded its imports by over $\$ 1 \mathrm{bn}$. Trade surplus stayed positive up to the end of 1984. A new era of a deficit balance in trade started in 1985 and this has continued to increase, to over $\$ 4.4 \mathrm{bn}$ in 2005 . The country has not seen a positive balance of trade since at least 1999 . Imports and exports follow the pattern of GDP fairly closely.

The most compelling story in Figure 3 is what happened between 1987 and 1989. With the escalation of unrest and turmoil in the Soviet Union and Communist bloc, the economies of east and central European countries began to shatter. Previously, Figure 1 has provided evidence of this in the case of Albania which, of course, was not a true Soviet bloc member and, hence, was shielded to some extent. In the case of Bulgaria, however, there is no doubt about what happened in that era up to the 1989 revolution. The economy of Bulgaria and, consequently, imports, exports and trade took a nose dive at the beginning, in 1987, and this did not stop until well after the revolution in 1991, when things began to improve gradually.

Figure 3 - Bulgaria's trade: actual, as \% of GDP and as \% of world trade

\section{Bulgaria, 1980-2005}

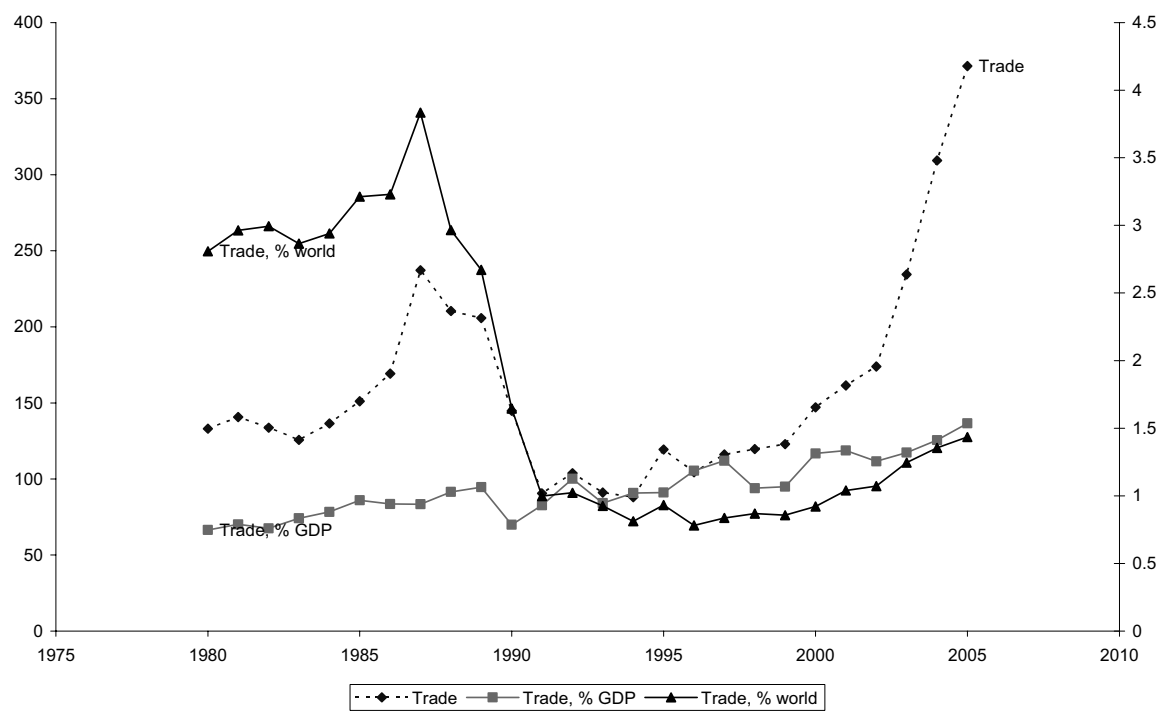

Note: The values for trade (scaled) and trade as a \% of GDP are shown on the left, while that of trade as a \% of world trade (scaled) is shown on the right-hand side. 


\section{Globalisation}

Bulgaria started with fairly high import and export percentages in 1980: i.e. $31 \%$ and $36 \%$, respectively, with these growing by 2005 to $76 \%$ and $60 \%$ respectively. Actual imports and exports, as well as the percentages of GDP, are reasonably close and change in tandem, indicating a healthy growth trend since 1991 which is in line with the growth in GDP. Nevertheless, the cumulative value of imports over this period, however, is slightly greater than the cumulative value of exports; on average, the country has had a negative balance of trade each year to the tune of about $\$ 530 \mathrm{~m}$. However, the majority of the negative balance has accrued since 1999; 2005 was the worst year, seeing a $\$ 4.4$ bn deficit. During the 26 years since 1980, exports as a percentage of GDP have increased from $36 \%$ to $60 \%$ while imports have more than doubled, from $31 \%$ to $76 \%$. Thus, a $\$ 1.0 \mathrm{bn}$ surplus turned into a $\$ 4.4 \mathrm{bn}$ deficit over this period. During the same period, Bulgaria's GDP grew about $36 \%$. Therefore, exports, and more so imports, have grown at a much faster pace than GDP.

It is interesting to glance at the graph of GDP, imports and exports. It is clear that, from 1987 to 1991, Bulgaria's economy suffered substantially. Actual GDP declined from $\$ 28.4$ bn to $\$ 10.9$ bn in just four years and this continued to decline for three more years, albeit at a much slower rate. After 1994, Bulgaria's GDP and, hence, imports and exports recovered. By 2005, GDP was just below the 1987 level, while exports and imports had increased substantially over their respective 1987 levels. It is not clear why both exports and imports each dropped by roughly $\$ 3 \mathrm{~m}$ in 1990, a year before the major decline in GDP. In the following year, everything dropped: GDP, exports and imports.

Referring to Figure 3, it is easy to notice the more or less steady line of trade as a percentage of GDP. It was explained above that imports and exports are in sync with GDP, which explains the steady line in Figure 3. However, the line also shows a slight incline which indicates a gradual globalisation, albeit a fairly faint one. This is supported in part by trade as a percentage of GDP nearing the $140 \%$ mark, which is considered high for the Balkan region.

\section{Globalisation compared to the world}

Bulgaria began with a relatively high share of world imports and exports, at $0.26 \%$ and $0.3 \%$ respectively. These shares grew until 1987 before dropping substantially and then continuing to drop for a long period until they reached $0.07 \%$ (in 1996) and $0.8 \%$ (in 1994) respectively. The gradual recovery over the next decade failed to raise the country's share of world trade to its earlier, higher values.

Figure 3 above reveals that Bulgaria has failed to recover, let alone regain, its position in global trade: in 1987, Bulgaria's share of world trade was above $0.38 \%$ but in 2005 , the highest level of recent years, it was barely $0.14 \%$ of world trade, a figure which was not even $40 \%$ of the 1987 level. Bulgaria's trade nears $140 \%$ of its GDP but, in spite of substantial growth in comparison with GDP, due to a very poor performance compared to world trade, the conclusion nevertheless is that, in the last decade, Bulgaria has missed the globalisation boat. 


\section{Croatia}

\section{Trade}

In 1991, Croatia proclaimed independence and was recognised as a country in January 1992. However, the subsequent war with local Serbs lasted until 1995. In the two years from 1991 to 1993, Croatia's GDP dropped from almost \$25bn to \$10.2bn. With this, both imports and exports of goods and services dropped in tandem, albeit that the former dropped slightly more, converting a $\$ 1.5 \mathrm{bn}$ trade deficit to a $\$ 560 \mathrm{~m}$ surplus; the only time the country has seen a trade surplus in fifteen years. Starting from 1993, the country started out on the long road to recovery. Since then, imports have increased more than exports and the gap between the two gradually widened until 2005, when the trade deficit exceeded $\$ 325 \mathrm{~m}$. In 2004 , the country finally managed to exceed its 1991 level of GDP. In the same year, exports also exceeded the 1991 level, following imports which had managed to reach that milestone during the prior year.

The big growth in GDP started in 2002, increasing by almost \$16bn and almost doubling in three years. The trade line (see Figure 4) shows the rapid increases between 1993 and 1997, and again from 1999 to 2005. The latter represents a substantial increase. During this period (in 2003), Croatia finally managed to exceed its pre-revolution trade. The rise in trade has been accomplished through increases in both imports and exports, which have been increasing together on a fairly consistent basis. Similarly-patterned increases in GDP reinforce the positive signals of trade. The only point of (long-run) concern is that imports have been consistently higher than exports.

\section{Figure 4 - Croatia's trade: actual, as \% of GDP and as \% of world trade}

\section{Croatia, 1991-2005}

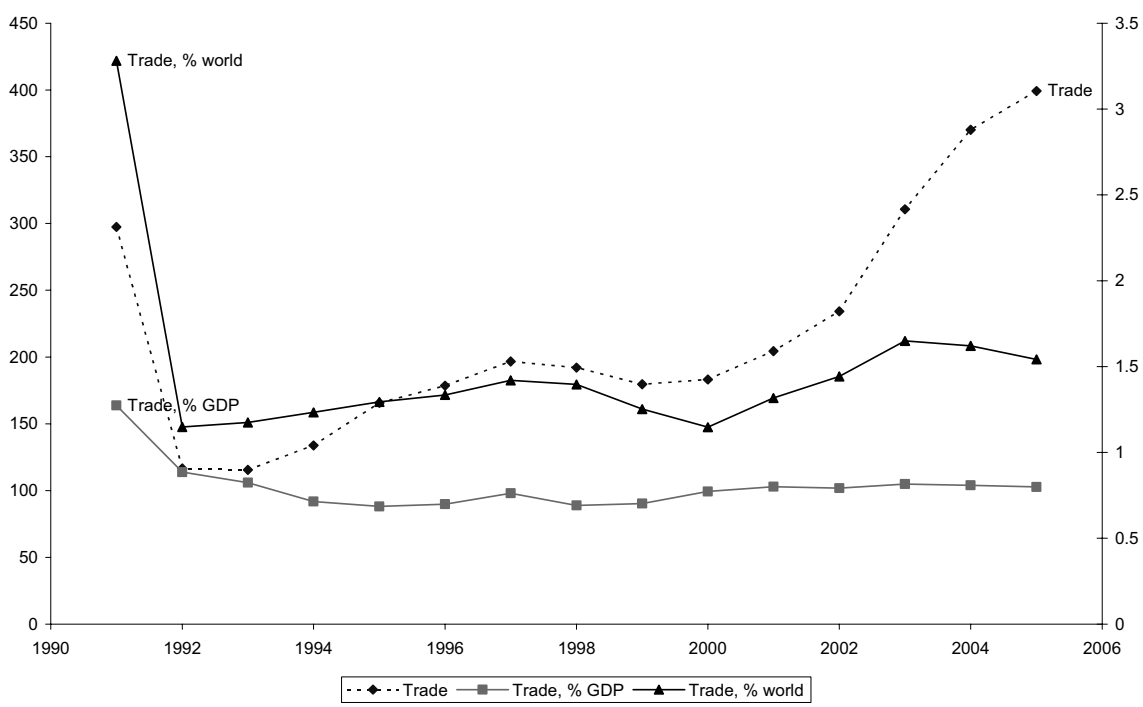

Note: The values for trade (scaled) and trade as a \% of GDP are shown on the left, while that of trade as a \% of world trade (scaled) is shown on the right-hand side. 


\section{Globalisation}

The decline in GDP in the year that the government changed and in the subsequent two years resulted in four years of decline in imports and five years of decline in exports as a percentage of GDP. This indicates that both imports and exports, and consequently trade, declined faster and longer than GDP (see Figure 4). In light of Croatia being involved in a civil war for five years, the decline in trade is not surprising. Both imports and exports operated at high percentages of GDP in 1991 (86\% and $78 \%$, respectively), before falling to the lows of 46\% and 39\% in 1994 and 1995 respectively. Exports have been hovering around this level, with a slight recovery since this time, remaining around the mid- to high- $40 \mathrm{~s}$ in percentage terms. Imports as a percentage of GDP have been floating around the mid-50s. The actual numbers for both imports and exports have been increasing at a slower rate than increases in GDP; hence, the percentages have not substantially increased, in spite of a fairly reasonable growth in both imports and exports. That Croatia's 'trade as a percentage of GDP' has continued to decline, finally stabilising at a level much lower than its pre-independence value in 1991, is not a reflection of low trade. On the contrary, it shows that a healthy increase in trade has been accompanied by a healthier increase in GDP. By 2003, the levels of GDP, imports and exports and, hence, trade had exceeded the respective figures for 1991 .

\section{Globalisation compared to the world}

In 1991, the share of Croatian exports in world exports declined sharply; that of imports was in an even sharper decline. In 1992, both shares dropped substantially, to below $0.12 \%$ and $0.11 \%$ respectively. The country never recovered and those shares remain at $0.14 \%$ and $0.17 \%$ respectively. Likewise, the country's trade never recovered after the decline that began around independence. It has been a decade since the end of the civil war, but it is still too early for a full recovery. With the exception of a relatively small setback between 1998 and 2000 (see Figure 4), Croatia's share of world trade has been holding its own and, at times, even gaining a little. Another positive indicator of a move towards greater globalisation is that total trade is slightly higher than $100 \%$ of GDP. Neither is growing appreciably, so Croatia is not considered a globalised nation.

\section{Macedonia}

\section{Trade}

Macedonia's recent history, like most other Balkan countries, begins in 1990. In 1992, Macedonia's GDP dropped to half its 1991 level - a common fact among Balkan countries for which data for these years are available. The exact magnitudes of the drop are somewhat different, but not by much. One factor that sets these countries apart is the length of time it took each country to recover from the shock. By 2003, most of the Balkans had passed the previous high levels, but it took Macedonia until 2003 to return to the 1991 level of GDP.

The decline resulted in no change in imports, although exports showed a substantial jump, exceeding $20 \%$. This behaviour of exports was unexpected, being contrary to the situations in other countries in the region. The increase in one year is more impressive since Macedonia is landlocked and since some of its neighbours were at war 
at this time and suffering substantial declines in their trade. Thereafter, both imports and exports continued their overall positive trends, picking up momentum in 2003. With the exception of 1992, both imports and exports have more or less moved in tandem with GDP. Consequently, trade has posted a solid gain, with minor setbacks in 1996 and 2001 (see Figure 5). Following 2001, Macedonia has seen a much faster growth in trade than it had previously recorded.

That Macedonia peacefully separated from Yugoslavia in 1991 does not mean that it has had less of a decline in GDP or trade. However, as is evident from Figure 5, trade recovered fairly quickly. The main nagging problem in this area is that imports exceed exports.

\section{Figure 5 - Macedonia's trade: actual, as \% of GDP and as \% of world trade}

\section{Macedonia, 1990-2005}

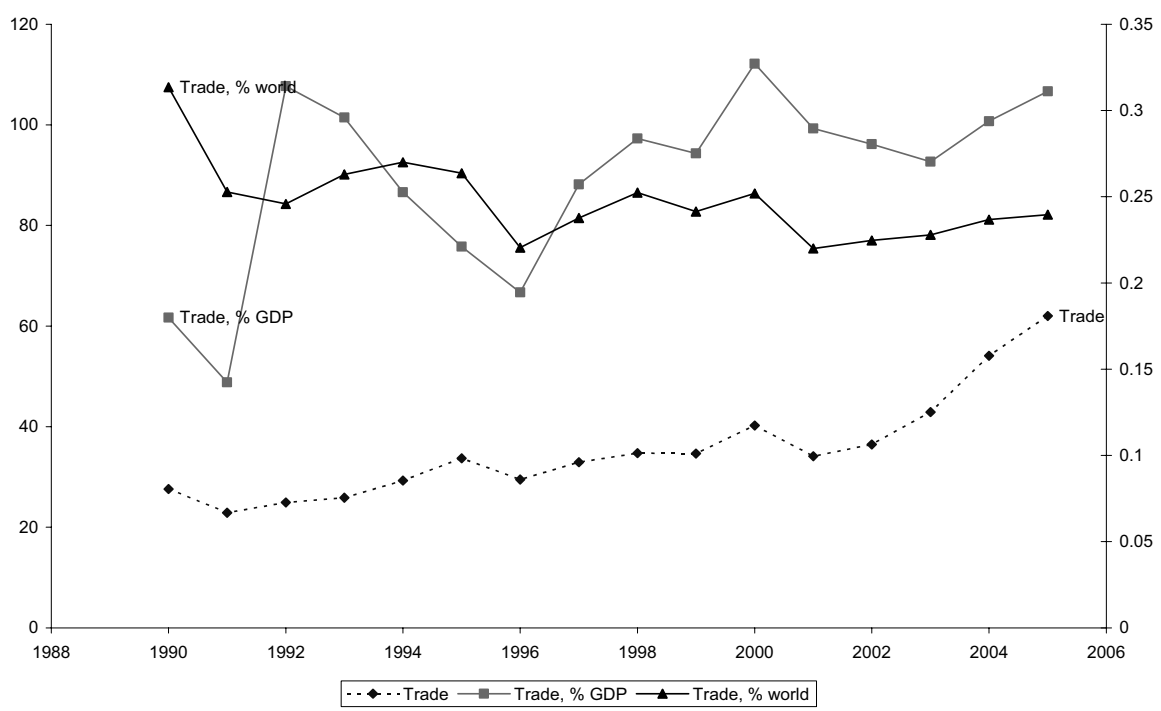

Note: The values for trade (scaled) and trade as a \% of GDP are shown on the left, while that of trade as a \% of world trade (scaled) is shown on the right-hand side.

\section{Globalisation}

During the sixteen years under study, increases in exports and imports were substantial: they were $26 \%$ and $36 \%$, respectively, of GDP in 1990 and increased to $45 \%$ and $62 \%$ of GDP in 2005. In fact, in two years, 2004 and 2005, combined exports and imports exceeded $100 \%$ of the level of GDP - a good sign of globalisation.

Trade as a percentage of GDP reports two major increases, one in 1992 and another from 1996 and 2002, after recovery from a decline between 1992 and 1996. Numerous fluctuations mask an overall sharp increase (see Figure 5). There are several indications that Macedonia has some of the characteristics of a global economy. In fact, its trade grew by more than 2.7 times between 1991 and 2005. 


\section{Globalisation compared to the world}

Macedonia's share of world imports was only $0.037 \%$ in 1990 but it dropped even lower in 2005 , to $0.028 \%$. The corresponding share for exports started even lower, at $0.026 \%$ in 1990 (the largest share of the entire period), dropping ultimately to $0.019 \%$ in 2005. The line for trade as a percentage of world trade indicates that Macedonia's share has been declining, with few exceptions. This is contrary to domestic information which indicates some trade improvements. The fact is that the country never truly recovered from its initial shock at independence. There is no evidence of a globalised economy. Nevertheless, as small as it may be, Macedonia's total trade exceeded $100 \%$ of its GDP on at least five occasions in these sixteen years.

\section{Montenegro}

\section{Trade}

With the collapse of Yugoslavia in 1992, Montenegro joined Serbia in a federation and it did not become an independent country until 2006. Data are available for the country since 2000 but, for all practical purposes, they are insufficient to establish any trends for its trade and other statistics under consideration.

During this short period, Montenegro has more than doubled its GDP from less than one billion to over two billion dollars, a healthy pace of growth which picked up momentum in 2002. Montenegro has had a negative balance of trade in all these years, in which the deficit increased from $\$ 141 \mathrm{~m}$ in 2000 to $\$ 392 \mathrm{~m}$ in 2005 . During this period, both imports and exports grew at a pace faster than the growth in GDP, while trade doubled (see Figure 6). There is no sign of any setbacks for trade.

\section{Figure 6 - Montenegro's trade: actual, as \% of GDP and as \% of world trade}

Montenegro, 2000-2005

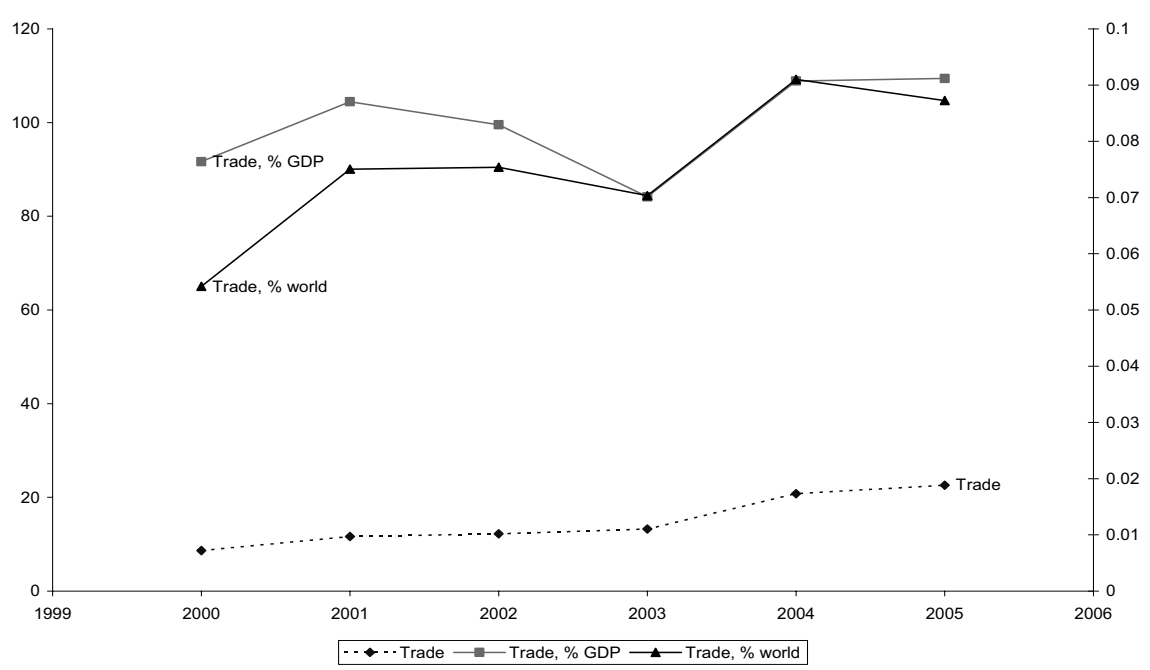

Note: The values for trade (scaled) and trade as a of GDP are shown on the left, while that of trade as a $\%$ of world trade (scaled) is shown on the right-hand side. 


\section{Globalisation}

Both imports and exports expressed as a percentage of GDP have seen modest increases over the six years for which there are data, being respectively $53 \%$ and $38 \%$ in 2000 and $64 \%$ and $45 \%$ in 2005. During the whole period, with the exception of 2003 , overall trade exceeded $90 \%$ of GDP, topping the $100 \%$ mark in three years. There is little evidence to hint at a trend (see Figure 6) but, based on relatively high values for trade as a percentage of GDP, Montenegro might be on the verge of globalisation.

\section{Globalisation compared to the world}

Montenegro has only six years of trade data. The share in world imports started at $0.0045 \%$ of world trade in 2000 and grew to $0.0072 \%$ in 2005; a modest gain of 1.58 times. The share in world exports in 2000 started at a high level, at $0.006 \%$, and ended the period at $0.01 \%$ in 2005; a gain of 1.61 times. Like most other smaller countries in the world, total trade as a percentage of GDP is fairly high, hovering around the $100 \%$ mark. The data for trade as a percentage of world trade (see Figure 6) provides the best evidence in support of a global economy. From 2000 to 2006, this percentage grew by over $60 \%$. Based on the small size of the country and the small share in world trade, it would be a stretch of the imagination to consider Montenegro's economy a global one but, for its size, it does have reasonably large trade sectors.

\section{Romania}

\section{Trade}

The communist government of Romania collapsed in 1989. With it, Romania's GDP suffered its only decline, which lasted just two years, from 1990-1992. It took from 1992 to 1995 for Romania to return to the previous peak level of GDP but, since then, GDP has described a steady pace, with one unusual increase and a subsequent correction. The pace of growth has increased substantially since 1999. From a low of $\$ 26 \mathrm{bn}$ in 1994, Romania's GDP increased by more than three times to $\$ 99 \mathrm{bn}$ in 2005. From their low point in 1991, exports have increased by 6.9 times while imports have grown by 6.4 times from their lowest value in the same initial year.

The country has had an increasing trade deficit throughout the period, which has grown from $\$ 3.6$ bn in 1990 to over \$10 billion in 2005. According to Figure 7, Romania's trade increased by almost $350 \%$ between 1990 and 2005. This increase is even more impressive if a comparison is made to the low value of 1991 (an increase of about 6.8 times). The greatest gains in trade came after 1999, with successively larger trades each year. This, combined with reasonable GDP growth, provides a good indicator of the globalisation of Romania. Imports are higher than exports, but not by that much. 
Figure 7 - Romania's trade: actual, as \% of GDP and as \% of world trade

Romania, 1990-2005

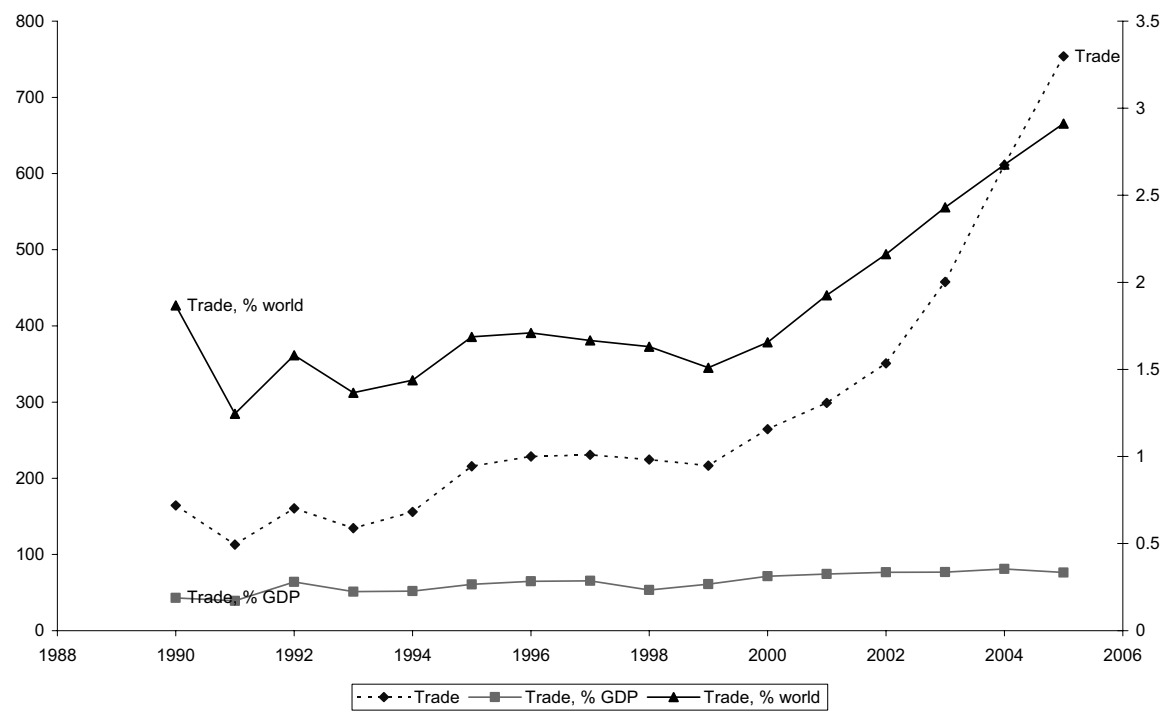

Note: The values for trade (scaled) and trade as a \% of GDP are shown on the left, while that of trade as a \% of world trade (scaled) is shown on the right-hand side.

\section{Globalisation}

Imports and exports as a percentage of GDP have been increasing on average. Imports were $26 \%$ of GDP in 1990, while exports were $17 \%$. By 2005, they had grown to $43 \%$ and $33 \%$ respectively (see Figure 7 ). Consequently, the trade deficit increased from \$3.6bn in 1990 to \$10.3bn in 2005. Combined trade was about $86 \%$ of GDP, which does not qualify for a globalised economy, while the line representing trade as a percentage of GDP in Figure 7 is curiously flat. Data comparing trade to GDP provides more support for the possibility of globalisation than does the graph. This is due to the anomalies and limitations of the graph, and its multiple scales. In this case, a high value of trade masks the relationship; this is more evident in the analysis provided by the next section.

\section{Globalisation compared to the world}

Romania's share of world exports was a respectable $0.14 \%$ in 1990 . The share of imports was even more impressive, at $0.22 \%$. These shares suffered a setback in 1991 and then fluctuated until 1999, when they took off to reach, respectively, $0.32 \%$ and $0.25 \%$ in 2005 . Neither the country's total trade as a percentage of GDP, nor the growth in its share of world trade, warrant labelling Romania as globalised. Romania's trade increased 6.5 fold from its lowest level in 1991 to its peak in 2005, while its share of world trade increased by more than 2.3 times. Nevertheless, the share of trade in GDP is not over 100\%, although this is not unusual for larger economies with fast-growing GDPs. 


\section{Serbia}

\section{Trade}

Like the majority of countries in the Balkans, Serbia became an independent country after the collapse of Yugoslavia. However, as is evident with the shortage of data (see Figure 8), it has been on a rocky path. Part of the reason for the lack of data is that, in 1991, three parts of the newly-formed Federal Republic of Yugoslavia separated, becoming Croatia, Slovenia and Macedonia. In 1992, Bosnia and Herzegovina separated. The country's numerous conflicts and wars within itself and with neighbouring countries lasted until 1999, when NATO helped end the hostilities and which devastated the country.

Serbia's limited data presents a sharp decline from 1997 to 2000 and an equally sharp increase from 2000 to 2005 in imports, exports and trade, surpassing the original peak. Imports and exports follow this pattern, although the former increased at a faster pace than the latter, widening a substantial trade deficit gap of \$1.1bn in 1998 to almost $\$ 5.8$ bn in 2005. Unfortunately, imports have grown at a much faster rate than GDP, while exports have grown at a substantially lower pace. As is evident, the country's trade increased soon after NATO's intervention and, since 1999, trade has tripled. The only negative point in this picture is that imports far exceed exports, which might - at least in part - be due to the presence of foreign forces.

\section{Figure 8 - Serbia's trade: actual, as \% of GDP and as \% of world trade}

\section{Serbia, 1997-2005}

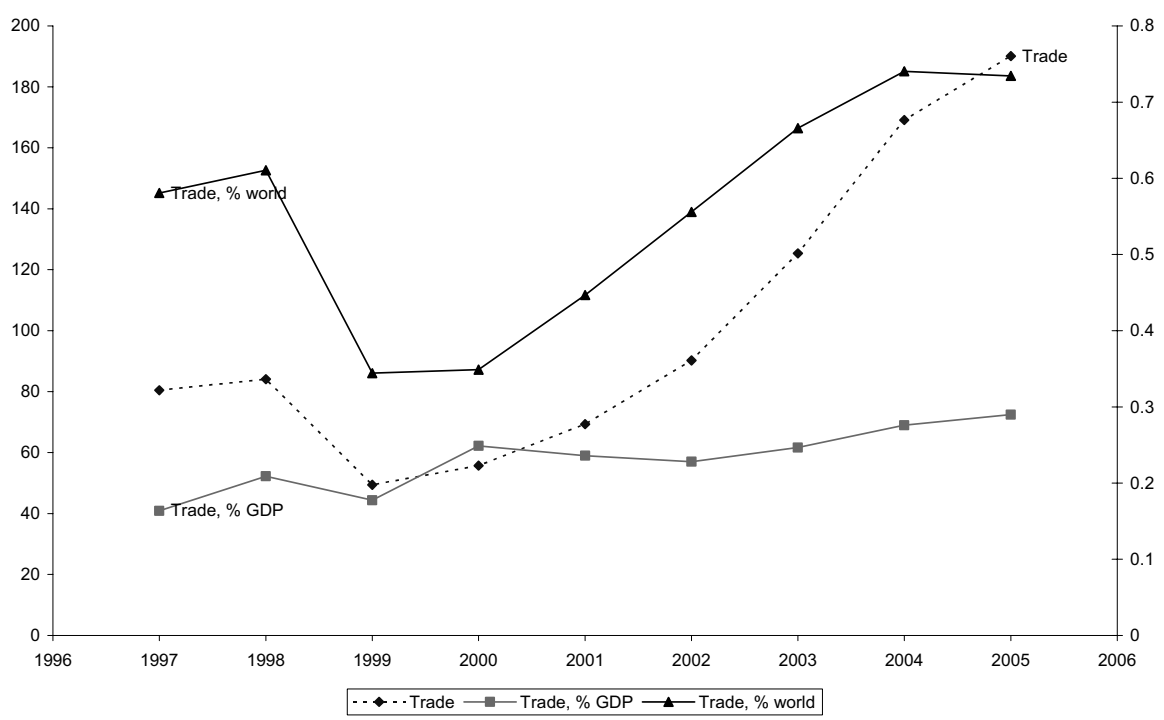

Note: The values for trade (scaled) and trade as a \% of GDP are shown on the left, while that of trade as a \% of world trade (scaled) is shown on the right-hand side. 


\section{Globalisation}

Both imports $(24 \%)$ and exports $(17 \%)$ as a percentage of GDP were at their lowest level in 1997 while both attained their peak (47\% and 25\% respectively) in 2005. Evidently, imports grew at a much faster pace than exports, which is not always a healthy sign of globalisation. Regardless, with a trade lower than $72 \%$ of GDP, Serbia is not considered globalised. The substantial increase in trade as a percentage of GDP is impressive (see Figure 8). An added factor is that, during this period, GDP increased by over $290 \%$. One reason for such a rapid increase in trade as a percentage of GDP is that it started from such a low level after the country was devastated by war.

\section{Globalisation compared to the world}

Serbia's imports and exports amount to $0.068 \%$ and $0.047 \%$ of world imports and exports respectively. These shares dropped to their lowest level in $1999(0.042 \%$ and $0.025 \%$ respectively), with imports then posting a healthy increase up to 2004 to $0.1 \%$, which is higher than the 1997 level. Exports climbed to $0.048 \%$ in 2005, which is not as high as the 1998 peak. In 2005, imports suffered a minor setback. The data does not provide any evidence of globalisation. Figure 8 also indicates the recovery of Serbia's trade as a percentage of world trade. By 2003, this indicator had surpassed the 1998 level. In fact, Serbia has managed to double its percentage of world trade within six years. This rapid increase is the best indicator of the globalisation of Serbia, although more data would provide better evidence of the direction of globalisation of the country.

\section{Conclusion}

In summary, with the exception of Macedonia and Montenegro, which can be considered globalised based on our crude measure of globalisation, the other countries seem not to have managed to join the latest globalisation surge, even partially. In contrast, Balkan countries should strive to benefit from the globalisation surge and not fail to join it.

Furthermore, trade flows in western Europe are becoming more concentrated on the European region itself, with more than two-thirds of Europe's exports and imports consisting of intra-west European exchanges, compared with some $55 \%$ and $46 \%$ in the inter-war period. Trade with the rest of the world, and especially with developing countries, has tended to decline in relative importance. Thus, the general evolution of European trade has not been towards a more global distribution of relationships but, instead, towards a more intense integration with close neighbours. Interdependence among the economies of the region has increased, but with the rest of the world, it has tended to weaken. Hence, open trade and foreign investment will supposedly lead not only to faster growth for the world economy but also to the increasing convergence of national incomes across the world.

On the positive side, the majority of Balkans countries show signs of growth in imports and exports. GDP is trending upwards throughout the region, while prospects of further income growth, as well as of European Union membership, are coherent. Geographical proximity to the west, significant market size and better stability could play a decisive role in the peninsula's economic and social prospects. 


\section{References}

Bitzenis, Aristidis (2005) 'Decisive Barriers that Affect Multinationals' Business in a Transition Country' Global Business \& Economics Review (Special Issue: The Political Economy of Transition) 8 (1/2): 87-118.

Bitzenis, Aristidis and John Marangos (2007) 'Globalisation and the IntegrationAssisted Transition in Central and Eastern European Economies' Journal of Economic Issues 61(2): 427-434.

Marangos, John (2001) 'International Trade Policies for Transition Economies: The Post Keynesian Alternative' Journal of Post Keynesian Economics 23(4): 689705.

Petrakos, George (2002) 'The Balkans in the New European Economic Space' Eastern European Economics 40(4): 6-30.

Sergi, Bruno S (2001) 'Do the Balkans Look West or Simply to the EU? From a Distorted Economy to a Prospective Open Economy' South-East Europe Review 4(3): 89-112.

Sergi, Bruno S (2003) Economic Dynamics in Transitional Economies: The Four-P Governments, the EU Enlargement and the Bruxelles Consensus New York: International Business Press.

Sergi, Bruno S. and Qerim R. Qerimi (2006) 'Business Perspectives in Southeast Europe' Transition Studies Review 13(3): 541-555.

Sergi, Bruno S and Qerim R. Qerimi (2008) The Political Economy of Southeast Europe from the 1990 to the Present: Challenges and Opportunities New York: Continuum.

worldbank.org/WBSITE/EXTERNAL/DATASTATISTICS/0,,contentMDK:21725423 pagePK:64133150 piPK:64133175 theSitePK:239419,00.html 